\title{
APRESENTAÇÃO
}

\section{Desafios teórico-metodológicos para o estudo do jornalismo: articulações entre cultura, poder e sociedade}

Apesar do lugar comum, é necessário reforçar que nosso ponto de partida é compreender a comunicação, primeiro, como fato cultural e político, e não técnico. Esse pressuposto implica em entender os meios de comunicação ou a tecnologia como elementos sociais, imbricados com os homens e suas ações e, portanto, em ruptura com a natureza. Contudo, as reflexões que mais se alastraram estão profundamente marcadas por uma visão concentrada nos objetos e seu funcionamento, embora elas possam ser mais otimistas ou mais sombrias em relação ao seu papel na sociedade.

O jornalismo se constitui como uma prática social estruturada nos mais diversos meios de comunicação, dos impressos, passando pelos audiovisuais e incorporando as mais novas tecnologias. Nos últimos tempos, as vozes mais ouvidas estão bastante identificadas com uma apologia do uso de múltiplas plataformas de produção e circulação do jornalismo, como também com a incorporação de sujeitos comuns em novos modos de produção de conteúdos. De um modo ou de outro, parecem ser vozes fascinadas pelas potencialidades de certas tecnologias e, inclusive, com seus efeitos na sociedade.

Do ponto de vista acadêmico, os estudos do jornalismo, ainda que tenham se intensificado ao longo dos últimos tempos, nos mais diversos quadrantes geográficos, permanecem restringindo seu objeto de estudo principalmente aos processos e produtos da rotina jornalística, bem como frequentemente se alinham a modelos interpretativos já consagrados onde muitas vezes as dimensões culturais de sua prática ficam achatadas. Por exemplo, quando seus resultados convergem para uma divisão rígida entre um jornalismo dito sério e 
outro, mais primitivo, fundado nas emoções e sentimentos, isto é resultado de um apagamento e/ou naturalização do fato de que tal divisão decorre de sua associação a um determinado projeto moderno de sociedade. As ilustrações abundam, também, quando se explicam determinadas práticas jornalísticas pela sua vinculação a critérios de noticiabilidade, sem problematização de sua pertinência a um determinado modelo de jornalismo, o que, mais uma vez, incide no achatamento de dimensões simbólicas.

O conjunto de textos que segue, na sua variedade e diversidade teórica, salutar em qualquer área de estudos, tem como objetivo tensionar esse olhar centrado em aspectos técnicos-profissionais do jornalismo, como também aquele marcado por uma obsessão tecnicista, evidenciando, de modos variados, dimensões culturais de sua prática. Originalmente, compuseram uma comunicação coordenada, intitulada Desafios teórico-metodológicos para o estudo do jornalismo: articulações entre cultura, poder e sociedade, que ocorreu durante $010^{\circ}$ Encontro da Sociedade Brasileira de Pesquisadores do Jornalismo (SBPJor), no ano passado, 2012. Alguns, de modo mais explícito, expressam um entendimento da prática jornalística como constituída e constituinte da esfera cultural e, assim, salientam sua forma simbólica. Outros, ainda, destacam que a prática jornalística deve ser pensada de modo integrado, incluindo tanto o âmbito da produção quanto o da recepção, incorporando os sujeitos que aí atuam e levando em conta o aspecto contextual - a prática jornalística, seus valores e produtos articulados a um determinado contexto histórico. Porém, todos exploram possibilidades teóricas e metodológicas alinhadas com um estudo do jornalismo que se relaciona com concepções sobre a sociedade, suas instituições e as relações de poder, daí a ideia de publicá-los em conjunto. 